\title{
Analysis of 20alpha-hydroxysteroid dehydrogenase expression in the corpus luteum of the buffalo cow: effect of prostaglandin F2-alpha treatment on circulating 20alpha-hydroxyprogesterone levels
}

Tripathy Sudeshna, Kumarasamy Anand and Rudraiah Medhamurthy*

\begin{abstract}
Background: During female reproductive cycles, a rapid fall in circulating progesterone (P4) levels is one of the earliest events that occur during induced luteolysis in mammals. In rodents, it is well recognized that during luteolysis, P4 is catabolized to its inactive metabolite, 20alpha-hydroxyprogesterone (20alpha-OHP) by the action of 20alpha-hydroxysteroid dehydrogenase (20alpha-HSD) enzyme and involves transcription factor, Nur77. Studies have been carried out to examine expression of 20alpha-HSD and its activity in the corpus luteum (CL) of buffalo cow.

Methods: The expression of 20alpha-HSD across different bovine tissues along with $C L$ was examined by qPCR analysis. Circulating P4 levels were monitored before and during PGF2alpha treatment. Expression of 20alpha-HSD and Nur77 mRNA was determined in $\mathrm{CL}$ at different time points post PGF2alpha treatment in buffalo cows. The chromatographic separation of P4 and its metabolite, 20alpha-OHP, in rat and buffalo cow serum samples were performed on reverse phase HPLC system. To further support the findings, 20alpha-HSD enzyme activity was quantitated in cytosolic fraction of $\mathrm{CL}$ of both rat and buffalo cow.

Results: Circulating P4 concentration declined rapidly in response to PGF2alpha treatment. HPLC analysis of serum samples did not reveal changes in circulating 20alpha-OHP levels in buffalo cows but serum from pseudo pregnant rats receiving PGF2alpha treatment showed an increased 20alpha-OHP level at $24 \mathrm{~h}$ post treatment with accompanying decrease in P4 concentration. qPCR expression of 20alpha-HSD in CL from control and PGF2alpha-treated buffalo cows showed higher expression at 3 and $18 \mathrm{~h}$ post treatment, but its specific activity was not altered at different time points post PGF2alpha treatment. The Nur77 expression increased several fold $3 \mathrm{~h}$ post PGF2alpha treatment similar to the increased expression observed in the PGF2alpha-treated pseudo pregnant rats which perhaps suggest initiation of activation of apoptotic pathways in response to PGF2alpha treatment.
\end{abstract}

Conclusions: The results taken together suggest that synthesis of P4 appears to be primarily affected by PGF2alpha treatment in buffalo cows in contrast to increased metabolism of P4 in rodents.

Keywords: Buffalo cow, Corpus luteum, PGF $2 a$, P4, 20a-HSD, 20a-OHP, Nur77

\section{Background}

In rats during pregnancy, catabolism of progesterone $\left(\mathrm{P}_{4}\right)$ to its inactive metabolite, 4-Pregnen-20 $\alpha$-ol-3-one i.e.

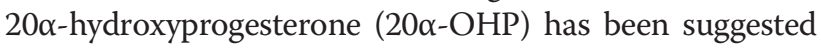
to be one of the key mechanisms for regulation of circulating $\mathrm{P}_{4}$ concentration both in maternal and fetal compartments

\footnotetext{
* Correspondence: rmm@mrdg.iisc.ernet.in

Department of Molecular Reproduction, Development and Genetics, Indian Institute of Science, Bangalore 560012, India
}

[1-3]. The enzyme, 20 $\alpha$-hydroxysteroid dehydrogenase (20 $\alpha$-HSD), classified as one of the members of aldo-keto reductase superfamily is responsible for conversion of

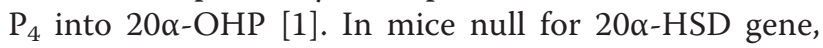
the length of estrous cycle and the duration of pseudo pregnancy and pregnancy periods were significantly prolonged although serum $\mathrm{P}_{4}$ levels decreased low enough for delivery of pups at term of pregnancy $[4,5]$. In pregnant goats, low concentration of $\mathrm{P}_{4}$ and high

\section{Biomed Central}


concentration of $20 \alpha-\mathrm{OHP}$ in the fetal blood, while high concentration of $\mathrm{P}_{4}$ and low concentration of $20 \alpha-\mathrm{OHP}$ in maternal blood have been reported [2]. In the baboon, the activity of $20 \alpha-H S D$ in placenta was observed to be higher with a corresponding increase in the concentration of $20 \alpha-\mathrm{OHP}$ in the fetal compartment during late pregnancy [3]. In many of these species, the observation of increased $20 \alpha-\mathrm{OHP}$ levels in the placenta is suggestive of regulation of $\mathrm{P}_{4}$ concentration by the feto-placental unit and/or parturition process. Since $20 \alpha-\mathrm{HSD}$ is essential for conversion of $\mathrm{P}_{4}$ into $20 \alpha-\mathrm{OHP}$, it can be suggested that $20 \alpha-H S D$ expression in placenta plays an important role during fetal development and/or parturition process. However, induction of $20 \alpha-H S D$ expression in the corpus luteum $(\mathrm{CL})$ is one of the striking features of luteolysis that occurs immediately prior to parturition and lactogenesis in pregnant rats [6,7].

During $\mathrm{PGF}_{2 \alpha}$-induced luteolysis, concomitant with the decreased $\mathrm{P}_{4}$ concentration, an increased concentration of $20 \alpha-\mathrm{OHP}$ has been reported in pregnant rats [8]. Rat cDNA expression array analysis findings have provided evidence for convergence of opposing actions of prolactin and $\mathrm{PGF}_{2 \alpha}$ on $20 \alpha-\mathrm{HSD}$ expression in the CL [9]. Furthermore, during $\mathrm{PGF}_{2 \alpha}$ treatment, an early association of increased expression of nerve growth factor-induced clone-B (NGFIB, also known as Nur77, NR4A1, among other designations) and $20 \alpha-$ HSD has been observed, that suggests participation of Nur77 in the induction of expression of $20 \alpha-H S D$ gene [8]. Nur77 which functions as transcription factor is a nuclear receptor protein belonging to steroid receptor superfamily and is suggested to play an important role in cell fate decisions [10]. Nur77 was originally characterized as immediate early response gene and has been shown to regulate expression of a number of steroidogenic genes in the ovary [11,12]. Also, Nur77 has been implicated as mediator of thymocyte and T-cell apoptosis [13,14]. Studies suggest that Nur77 induces apoptosis by activation of genes involving both extrinsic and intrinsic apoptotic pathways $[15,16]$.

Despite extensive research, the cellular and molecular mechanisms involved in the $\mathrm{PGF}_{2 \alpha}$-induced luteal regression remains poorly understood. At present, with the exception of studies in rodents, reports of examination of $20 \alpha-\mathrm{HSD}$ expression in CL of other species are sparse $[17,18]$. Moreover, whether $\mathrm{P}_{4}$ undergoes catabolism in the $\mathrm{CL}$ during spontaneous and $\mathrm{PGF}_{2 \alpha}$-induced luteolysis has not been reported in other species. It should be pointed out that the function of $\mathrm{CL}$ in bovine species unlike species such as primates is largely under the control of luteolytic factor, $\mathrm{PGF}_{2 \alpha}$. With a view to further gain insights into the $\mathrm{PGF}_{2 \alpha}$-induced luteolysis, several experiments were carried out in the buffalo cows with the following objectives: 1 ) To study $20 \alpha$-HSD expression in various tissues including the CL of the buffalo cow,
2) To examine expression of Nur77, expression and activity of $20 \alpha$-HSD during the $\mathrm{PGF}_{2 \alpha}$-induced luteolysis in the buffalo cow, and 3) To determine the concentration of $20 \alpha-\mathrm{OHP}$ during $\mathrm{PGF}_{2 \alpha}$-induced luteolysis. The experiments involving well established rat model for $\mathrm{PGF}_{2 \alpha^{-}}$ induced 20 $\alpha$-HSD expression and activity were included for purposes of comparison with buffalo cow experiments.

\section{Methods}

\section{Reagents}

Juramate $^{\oplus}$ (Cloprostenol sodium, the synthetic analogue of $\mathrm{PGF}_{2 \alpha}$ ) was purchased from Jurox, Australia. $\mathrm{P}_{4}$ (GDN\#337) antisera was kindly provided by Prof. G.D. Niswender, Colorado State University, Fort Collins, CO. DyNAzyme $^{\text {тм }}$ II DNA polymerase was obtained from Finnzymes, Espoo, Finland. Moloney murine lukemia virus $(\mathrm{MMuLV})$ reverse transcriptase $\left(\right.$ Revert $\left.\mathrm{Aid}^{\mathrm{Tx}}\right)$, RNase inhibitor (RNasein), $10 \mathrm{mM}$ dNTP mix and $100 \mathrm{bp}$ ladder were obtained from MBI Fermentas, Germany. NADP (disodium salt) and NADPH (tetra sodium salt) was obtained from HiMedia Laboratories Pvt. Ltd., Mumbai, India. Reference standards for 4-Pregnen-20 $\alpha$-ol-3-one (20 $\alpha-\mathrm{OHP})$ and $\mathrm{P}_{4}$ were obtained from Sigma-Aldrich, Bangalore, India. Oligo dT and oligonucleotide primers were synthesized by Sigma-Genosys, Bangalore, India. The high performance liquid chromatography (HPLC) grade acetonitrile was obtained from Qualigens, Mumbai, India. All other reagents were purchased from SigmaAldrich, Bangalore, India or sourced through local suppliers.

\section{Animals, experimental protocol, blood and CL collection schedule}

\section{Experiments in buffalo cows}
a. Collection of different organs for assessment of $20 \alpha-H S D$ mRNA expression

Non lactating adult buffalo cows (Bubalus bubalis; Surthi breed) aged 5-6 years with a known history of normal cyclicity were recruited for the study. Tissues such as spleen, brain, skeletal muscle, kidney, mammary gland, lung, heart, liver, myometrium and CL ( $n=3$ /tissue) were collected to analyse the expression of $20 \alpha-\mathrm{HSD}$ across different tissues.

\section{b. Characterization of $\mathrm{PGF}_{2 \alpha}$ effects on $\mathrm{CL}$ function}

The day of onset of estrus was designated as day 0 of estrous cycle. To verify the presence of functional CL, blood samples were collected on days 3 to 7 of the cycle for monitoring circulating $\mathrm{P}_{4}$ concentration. In this experiment, Juramate $\left(\mathrm{PGF}_{2 \alpha}\right)$ was administered $500 \mu \mathrm{g}$ i.m., on day 11 of estrous cycle and CL was 
collected immediately before $(0 \mathrm{~h}), 3,6,18$ and 36 and $60 \mathrm{~h}$ post $\mathrm{PGF}_{2 \alpha}$ injection. Blood samples were collected immediately before ( $\mathrm{n}=9$ animals) and at different time intervals ( $\mathrm{n}=6$ animals/ time point) post $\mathrm{PGF}_{2 \alpha}$ injection for determining serum $\mathrm{P}_{4}$ levels. Ovaries containing $\mathrm{CL}$ ( $n=3 /$ time point) were collected post slaughter and washed in sterile ice cold PBS and transferred into Dulbecco's Modified Eagles Medium supplemented with penicillin $(500 \mathrm{U} / \mathrm{ml})$ and streptomycin $(50 \mu \mathrm{g} / \mathrm{ml})$ and transported to the laboratory on ice within $30 \mathrm{~min}$ of collection. Under sterile conditions, CL was extirpated, cut into eight to twelve pieces, transferred to labelled cryovials, snap frozen in liquid nitrogen and stored at $-70^{\circ} \mathrm{C}$ until analysis.

\section{Experiment in rats}

Effect of $\mathrm{PGF}_{2 \alpha}$ treatment on luteal function in rats It is well documented that $\mathrm{PGF}_{2 \alpha}$ treatment increases $20 \alpha-$ HSD expression in the CL and circulating $20 \alpha-\mathrm{OHP}$ in pseudo pregnant rats $[8,19]$. We utilized pseudo pregnant rat model system to serve as reference (with regard to post $\mathrm{PGF}_{2 \alpha}$ treatment related rise in $20 \alpha-\mathrm{HSD}$ expression and 20 $\alpha$-OHP concentration) for $\mathrm{PGF}_{2 \alpha}$ studies in buffalo cows. Three month old adult female rats (Wistar strain) were housed in a controlled environment and kept under a photoperiod of $12 \mathrm{~h}$ light and $12 \mathrm{~h}$ of darkness cycle with ad libitum access to food and water. Pseudo pregnancy was induced in female rats by cohabitation with vasectomised male rats on the afternoon of proestrus. Following cohabitation, female rats were examined for the presence of vaginal plug and/or subjected to screening of vaginal smears daily for the extension of the diestrus period. The presence of vaginal plug and/ or upon confirmation of day 1 of continuous diestrus (observed for 3 consecutive days) following cohabitation with vasectomised male rats was designated as day 1 of pseudo pregnancy. The status of pseudo pregnancy was further confirmed by determining the presence of higher $\left(>50 \mathrm{ng} / \mathrm{ml}\right.$ ) circulating serum $\mathrm{P}_{4}$ concentration on day 5 of pseudo pregnancy. On day 8 of pseudo pregnancy, rats were injected i.p. with PBS (control) or $10 \mu \mathrm{g} / 100 \mu \mathrm{l}$ of Juramate ${ }^{\circ}\left(\mathrm{PGF}_{2 \alpha}\right)$. Blood ( $\mathrm{n}=5$ animals/time point) and CL ( $\mathrm{n}=5$ animals/time point) were collected before and $24 \mathrm{~h}$ post treatments.

All procedures in animals were approved by the Institutional Animal Ethics Committee, Indian Institute of Science, Bangalore, India.

\section{Hormone assays}

Serum $\mathrm{P}_{4}$ concentrations were determined by specific radioimmunoassay as reported previously [20]. The sensitivity of the assay was $0.1 \mathrm{ng} / \mathrm{ml}$ and the interand intra- assay coefficients of variation were $<10 \%$.

\section{RNA isolation}

Total RNA was extracted from control and $\mathrm{PGF}_{2 \alpha}$ treated samples using Tri Reagent according to the manufacturer's recommendations, as reported previously [20]. RNA was quantitated spectrophotometrically using ND-1000 (NanoDrop, Thermo Scientific, Wilmington, DE, USA). The quality and quantity of RNA were determined by electrophoresis on a $2 \%(\mathrm{w} / \mathrm{v})$ formaldehyde agarose gel along with RNA samples of known concentration and $\mathrm{A}_{260}: \mathrm{A}_{280}$ ratio was $>1.8$.

\section{Semi quantitative RT-PCR}

Semi quantitative RT-PCR analysis for $20 \alpha-H S D$ was carried out as described previously from the laboratory [20]. L19 expression was used to check for the efficiency of RT-PCR. The primers used for $20 \alpha-H S D$ gene were F:5' -CTGTAACCAGGTCGAATGTCAC-3' and R:5'-GG GTAGTTCGGGTTCACCC-3'; and for L19 were F:5'CCACATGTATCACAGCCTGTAC-3' and R:5'-CTT GGTCTTAGACCTGCGG-3'. Primers were designed from recently reported cattle sequences submitted by Naidansuren et al., 2011 [17] [GenBank: GU064907] using Primer Express ${ }^{\mathrm{Tm}}$ version 2.0 (Applied Biosystems, Foster City, CA, USA) spanning the exon-exon junctions. PCR products were resolved on $2 \%$ Tris- acetate-EDTA agarose gels containing ethidium bromide $(0.5 \mu \mathrm{g} / \mathrm{ml})$, and photographed under UV light and analysed using GBox chemi-HR16, gel documentation system (Synoptics Ltd, Cambridge, UK). The amplified PCR product was eluted and cloned into pGEM-T easy vector system I, sequenced and the nucleotide analysis revealed $71 \%$ homology with bovine placental and ovary $20 \alpha-H S D$ sequence [17].

\section{Quantitative real time PCR (qPCR)}

The analysis was carried out as described previously from the laboratory [21]. The cDNA samples equivalent to $10 \mathrm{ng}$ of total RNA were subjected to validation analysis on Applied Biosystems 7500 Fast Real Time PCR system with SDS v 1.4 program employing Power SYBR green 2X PCR master mix. The following primers were used for analysis, for 20 $\alpha$-HSD gene, F:5'-CTGTAACCAGGTCG AATGTCAC-3' and R:5'-GGGTAGTTCGGGTTCACC C-3'; for Nur77 gene, F:5'-CTTCTTCAAGCGCACAG TGCAG-3' and R: 5'-CTGTCTGTCCGGACAACTTCC TTC-3' and for L19 gene, F:5'-CCACATGTATCACA GCCTGTAC-3' and R:5'-CTTGGTCTTAGACCTGCGG$3^{\prime}$. Primers were designed using cattle sequences submitted at NCBI and ENSEMBL using Primer Express ${ }^{\mathrm{Th}}$ version 2.0 (Applied Biosystems, Foster City, CA, USA). The primers were designed to cover the exon- exon junctions. Real time PCR efficiencies were acquired by amplification of a standard dilution series (with 10 fold differences) in the Applied Biosystems 7500 Fast Real time PCR system with SDS v 1.4 program employing Power SYBR Green 
2X PCR mix. The corresponding efficiencies (E) for $20 \alpha-H S D$ and Nur77 were calculated according to the equation: $\mathrm{E}=10^{[-1 / \mathrm{slope}]}-1$ [22] and an efficiency of $>90 \%$ was obtained for both. Analysis of expression of each gene included a no template control (NTC) and generation of a dissociation curve. Expression levels of the genes validated were normalized by using L19 expression levels as calibrator (internal control) for each cDNA sample. The relative expression and fold change in gene expression was determined using $\Delta \mathrm{C}_{\mathrm{t}}$ and $\Delta \Delta \mathrm{C}_{\mathrm{t}}$ method, respectively.

Relative expression $=2^{-\Delta \mathrm{Ct}}$ and fold change $=2^{-\Delta \Delta \mathrm{Ct}}$, where $C_{t}=$ Threshold cycle i.e. the cycle number at which the relative fluorescence of test samples increases above the background fluorescence, $\Delta C_{t}=\left[C_{t}\right.$ gene of interest (unknown sample) $-C_{t}$ of L19 (unknown sample)] and $\Delta \Delta C_{t}=\left[C_{t}\right.$ gene of interest (unknown sample) $-C_{t}$ of L19 (unknown sample) $]-\left[C_{t}\right.$ gene of interest (calibrator sample) $-\mathrm{C}_{\mathrm{t}}$ of L19 (calibrator sample)]. PCR for each sample was set up in duplicates and the average $C_{t}$ value was used in the $\Delta \Delta C_{t}$ equation.

\section{HPLC analysis \\ HPLC unit}

The chromatographic separation of $\mathrm{P}_{4}$ and its metabolite, 20 $\alpha$-OHP was performed on reverse phase HPLC system (Agilent 1200). Samples were injected via thermostated autosampler. The stationary phase was a Zorbax Eclipse Plus C18 $5 \mu \mathrm{m}$ column $(4.6$ X $250 \mathrm{~mm})$ comprising of dense monolayer of dimethyl-n-octadecylsilane stationary phase with improved ultrahigh purity Zorbax Rx-SIL porous silica support. The thermostatted column compartment was used at an ambient temperature of $25^{\circ} \mathrm{C}$. The readings at $245 \mathrm{~nm}$ were taken using variable UV wavelength detector. The mobile phase was a mixture of water ( $\mathrm{pH} 3.4$ ) and acetonitrile with gradient elution from 20 to $66 \%$ acetonitrile in $9 \mathrm{~min}$ (held for $3 \mathrm{~min}$ ), then from 66 to $100 \%$ acetonitrile in $22 \mathrm{~min}$. Standards for $\mathrm{P}_{4}$ and $20 \alpha-O H P$ were run on HPLC to determine the elution time separately, as well as, together.

\section{Standard and sample preparation and extraction}

For HPLC analysis, known concentration of $\mathrm{P}_{4}$ and $20 \alpha-$ OHP standards were diluted in steroid free serum. To remove steroids, $10 \mathrm{ml}$ of bullock serum was treated with $0.5 \mathrm{~g}$ of activated charcoal and stirred for $2 \mathrm{~h}$ at $4^{\circ} \mathrm{C}$. The slurry was centrifuged at $1750 \mathrm{X}$ g for $10 \mathrm{~min}$. The clear supernatant was collected and stored as 1-2 ml aliquots at $-20^{\circ} \mathrm{C}$.

The lipid extraction from serum samples was carried out by addition of methanol-diethyl ether mixture. For rat serum extraction ( $n=5 /$ time point), $500 \mu \mathrm{l}$ of serum was mixed with $50 \mu \mathrm{l}$ methanol and $5 \mathrm{ml}$ diethyl ether, vortexed manually for $2 \mathrm{~min}$ and solvents containing lipids were separated after precipitating aqueous phase in liquid nitrogen and evaporating the solvent on a $37^{\circ} \mathrm{C}$ water bath. After repeating the procedure two more times, the extracted lipid was reconstituted in $10 \%$ acetonitrile. For bovine serum ( $n=5 /$ time point) lipid extraction, same procedure as used for rat serum was followed but with $2.5 \mathrm{ml}$ serum volume. The samples were run on the HPLC column as mentioned earlier. The run was analysed drawing chromatograms using the Agilent Chemstation software and the runs were compared with $\mathrm{P}_{4}$ and $20 \alpha-\mathrm{OHP}$ standards.

\section{Preparation of $\mathrm{CL}$ tissue cytosolic fraction}

All procedures were performed at $4^{\circ} \mathrm{C}$. Frozen $\mathrm{CL}$ tissues (10-15 mg wet weight) from rat and buffalo cows were homogenized in $500 \mu \mathrm{l}$ of potassium phosphate buffer (5 mM, pH 7.0) containing $1 \mathrm{mM}$ EDTA, $1 \mathrm{mM}$ dithiothreitol and $10 \%$ glycerol. Protease inhibitors, $1 \mathrm{mM}$ phenylmethanesulfonyl fluoride and $20 \mu \mathrm{g}$ of leupeptin $/ \mathrm{ml}$ and $40 \mu \mathrm{g}$ of aprotenin $/ \mathrm{ml}$ were used. The homogenate was centrifuged at 10,500 X g for $90 \mathrm{~min}$. The supernatant was used as the cytosolic fraction.

\section{Measurement of luteal 20a-HSD activity}

The activity of $20 \alpha-$ HSD was determined by the method of Wiest et al., 1968 [6] with a few modifications. The assay medium was Tris- $\mathrm{HCl}$ buffer solution $(0.1 \mathrm{mM}$, $\mathrm{pH}$ 8.0) containing $30 \mu \mathrm{M} 20 \alpha-\mathrm{OHP}, 300 \mu \mathrm{M}$ NADP, $1 \mathrm{mM}$ EDTA, $5 \mathrm{mM}$ dithiothreitol and 3\% ethanol for sterol solubilisation; dithiothreitol and NADP were added immediately before use. The enzyme reaction was initiated at $37^{\circ} \mathrm{C}$ by adding $12.5 \mu \mathrm{l}$ sample into the assay medium with rapid mixing. The OD values were recorded spectrophotometrically at $340 \mathrm{~nm}$ for $3 \mathrm{~min}$. For sample blank, the cytosolic fraction was mixed with reaction buffer and OD values were recorded. The change in the concentration of NADPH formed in samples was calculated from the NADPH standard graphs. The enzyme activity was defined as the amount of enzyme that could induce $1 \mathrm{nmol}$ $\mathrm{NADPH} \mathrm{min}^{-1} \mathrm{mg}^{-1}$ protein at $37^{\circ} \mathrm{C}$.

\section{Statistical analysis}

Where applicable, data were expressed as mean \pm SEM. The arbitrary densitometric units were represented as relative mRNA expression after dividing the band intensity for L19 of the corresponding sample. Comparisons between mean of two groups were carried out using a non-parametric test, Mann-Whitney test, without assuming the Gaussian distribution. For multiple comparisons, the data were analyzed by one way ANOVA, followed by the Newman-Keuls multiple comparison test (PRISM Graph Pad, version 5; Graph Pad Software, Inc., San Diego, CA). A p-value of $<0.05$ was considered to be significant. 


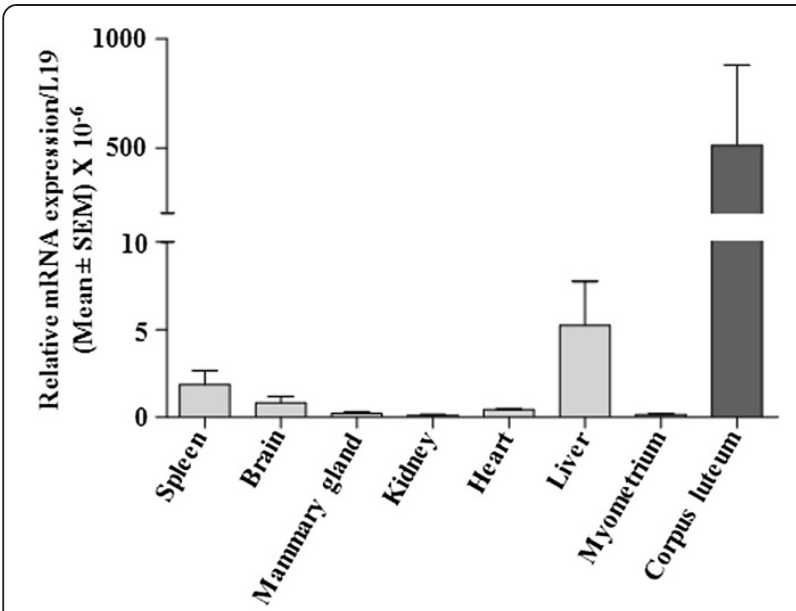

Figure 1 Quantitative real time PCR expression of 20a-HSD mRNA in different tissues of buffalo cows. 20a-HSD expression was normalized to L19 and the 20a-HSD mRNA expression is represented as relative expression level.

\section{Results}

\section{Expression of 20a-HSD in various tissues}

The qPCR expression of $20 \alpha-H S D$ mRNA was determined in various tissues of the buffalo cow and the results are presented in Figure 1. The mRNA expression was high in the CL and the expression was also detectable in spleen, brain and liver. However, the expression was low in mammary gland, kidney, heart and myometrium (Figure 1). In lung and skeletal muscle tissues, expression was undetectable (data not shown).

Effects of $\mathrm{PGF}_{2 a}$ treatment on circulating $\mathrm{P}_{4}$ levels, luteal expression of 20a-HSD and Nur77 in the buffalo cow Circulating $\mathrm{P}_{4}$ concentration in buffalo cows on day 11 of estrous cycle immediately before $\mathrm{PGF}_{2 \alpha}$ injection was $4.0 \pm 0.34 \mathrm{ng} / \mathrm{ml}$, and the concentrations were $1.23 \pm$
$0.12,1.09 \pm 0.18$ and $0.76 \pm 0.09 \mathrm{ng} / \mathrm{ml}$ at 3,6 and $18 \mathrm{~h}$ post treatment, respectively (Figure 2A). A significant $(\mathrm{p}<0.001)$ decrease in $\mathrm{P}_{4}$ concentration was observed within $3 \mathrm{~h}$ post treatment and the concentrations further declined at 6 and $18 \mathrm{~h}$ time points. The fold change in

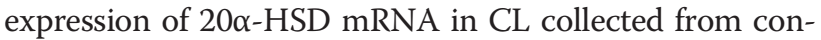
trol and $\mathrm{PGF}_{2 \alpha}$ treated animals are presented in Figure 2B. The 20 $\alpha$-HSD mRNA expression was 4-7 fold higher after $\mathrm{PGF}_{2 \alpha}$ treatment (Figure 2B). qPCR expression of Nur77 was $>15$ fold higher at $3 \mathrm{~h}$ post $\mathrm{PGF}_{2 \alpha}$ injection, however, the expression at other time points post $\mathrm{PGF}_{2 \alpha}$ injection was not significantly different from CL of $\mathrm{PGF}_{2 \alpha}$ untreated buffalo cows i.e. time 0 time point (Figure 2C).

\section{Analysis of $\mathrm{P}_{4}$ and $20 a-O H P$ concentrations in biological samples by HPLC}

After performing standardization of various parameters including standardization of the appropriate injection volume $(10 \mu \mathrm{l})$ for determining the minimum detectable steroid concentration $(2 \mathrm{ng} / 10 \mu \mathrm{l})$ and retention time

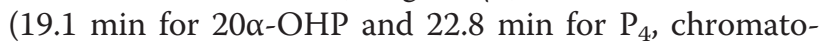
grams not shown), known standards of varied concentrations of $\mathrm{P}_{4}$ and $20 \alpha-\mathrm{OHP}$ either alone or after mixing both of them were run on a Zorbax eclipse Plus C18 column. The chromatogram patterns for a range of concentrations of mixture of $\mathrm{P}_{4}$ and $20 \alpha-\mathrm{OHP}$ standards are shown in Figure 3. The area under peak (AUP) for each steroid was calculated and the data is presented in Table 1 . The chromatogram patterns for fixed concentration of each steroid was also generated in order to rule out that the chromatogram pattern generated in mixture of two steroids was not different compared to pattern when fixed concentration of steroid was run (Figure 3). The representative chromatogram shown in Figure 3, shows an AUP of 120.44, 28.27, 8.73 and 1.96 units for 33, 10, 3.33 and $1 \mathrm{ng} / 10 \mu \mathrm{l}$ (Figure 3A-D) of
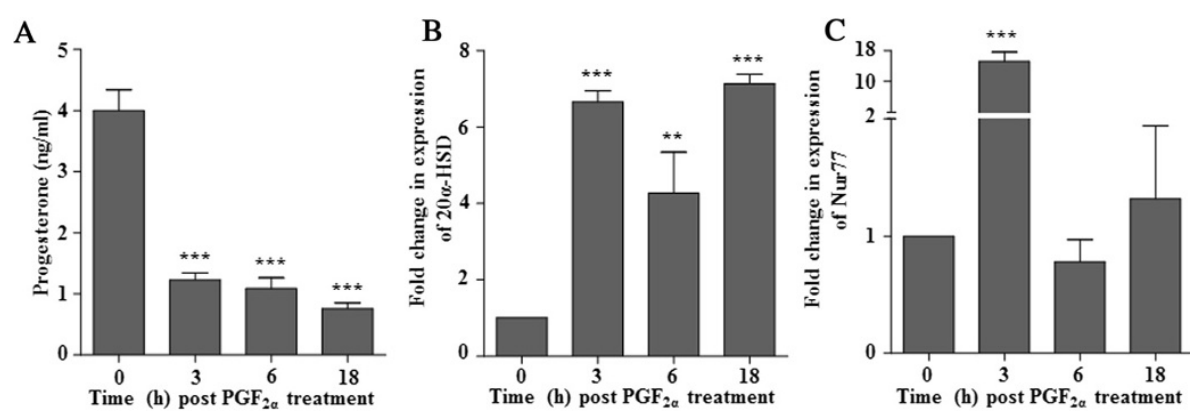

Figure 2 Effect of $\mathrm{PGF}_{2 a}$ treatment on serum progesterone, luteal 20a-HSD and Nur77 mRNA expressions. Buffalo cows received intramuscular injection of $500 \mu \mathrm{g}$ of $\mathrm{PGF}_{2 a}$ on day 11 of estrous cycle and blood and luteal tissue samples were collected at 0,3,6 and $18 \mathrm{~h}$ post $\mathrm{PGF}_{2 a}$ treatment. (A) Mean $( \pm \mathrm{SEM})$ circulating serum progesterone $\left(\mathrm{P}_{4}\right)$ concentration immediately before $(0 \mathrm{~h})$ and after $(3,6 \mathrm{and} 18 \mathrm{~h})$ the $\mathrm{PGF} \mathrm{F}_{2 a}$ treatment in buffalo cows, $\left.{ }^{* * *} \mathrm{p}<0.001\right)$. (B) qPCR expression of 20a-HSD mRNA levels in the CL from buffalo cows collected at 0, 3, 6 and $18 \mathrm{~h}$ post $\mathrm{PGF}_{2 a}$ treatment with the expression normalized with $L 19$ mRNA. (C) qPCR expression of Nur77 mRNA levels in the CL from buffalo cows collected at 0, 3, 6 and $18 \mathrm{~h}$ post PGF 2 treatment and the expression was normalized with L19 mRNA. The results are shown as fold changes of mRNA expression compared with that at $0 \mathrm{~h} \mathrm{PGF}_{2 a}$. Bar represents mean $\pm \mathrm{SEM}, \mathrm{n}=3,{ }^{* * *} \mathrm{p}<0.001$ and ${ }^{* *} \mathrm{p}<0.01$ versus control ( 0 h). 


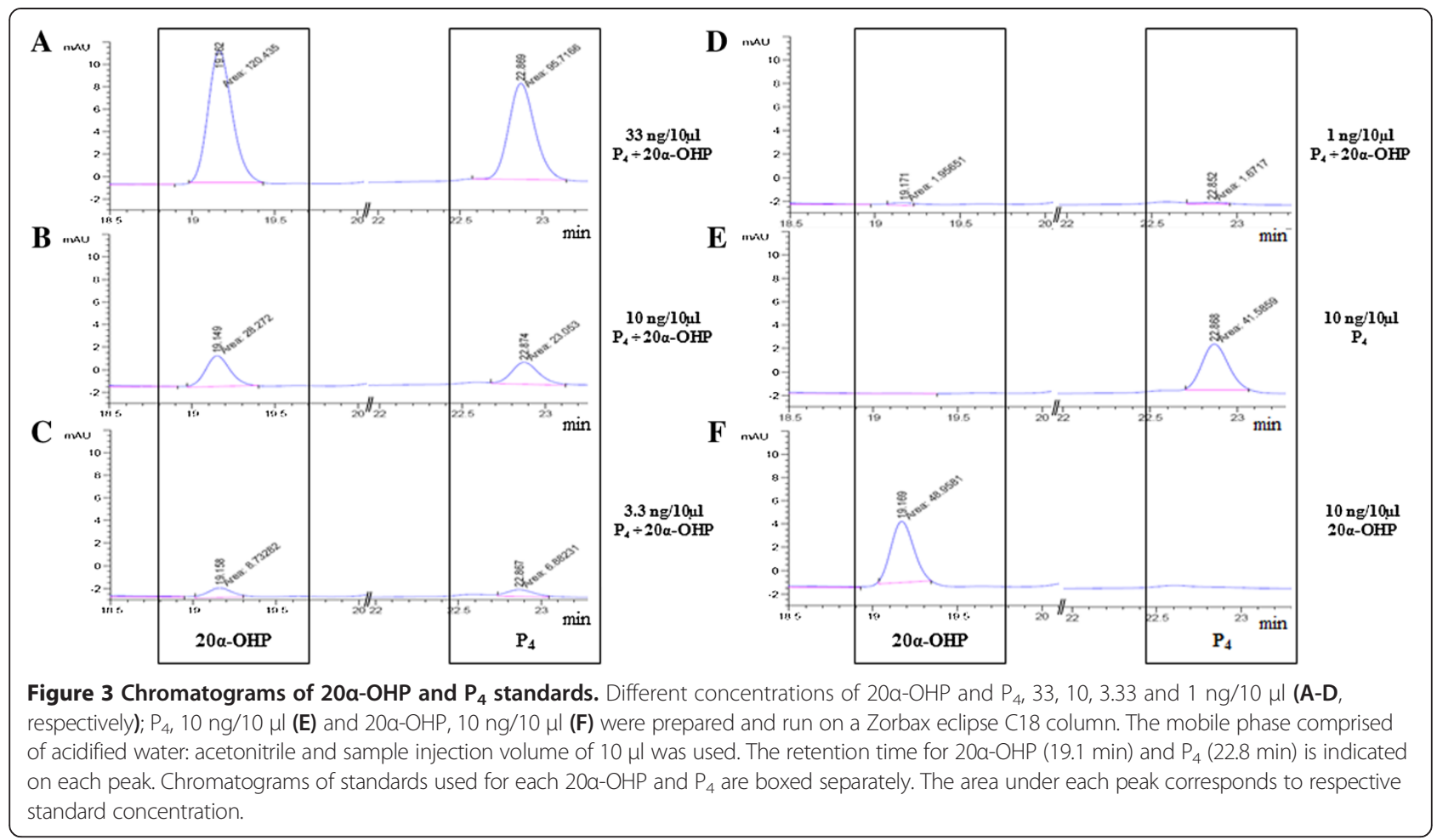

$20 \alpha-O H P$, respectively. Further, an AUP of 95.72, 23.05, 6.89 and 1.67 units for 33, 10, 3.33 and $1 \mathrm{ng} / 10 \mu \mathrm{l}$ (Figure 3A-D) is observed for $\mathrm{P}_{4}$, respectively.

The profile for each steroid was determined on HPLC column for serum samples collected from rats $24 \mathrm{~h}$ after PBS (vehicle) or $\mathrm{PGF}_{2 \alpha}$ injection (Figure $4 \mathrm{~B}$ and $\mathrm{C}$ ) and the aggregate values for AUP is represented in Table 2. The AUP for $20 \alpha-O H P$ in serum was significantly increased $(\mathrm{p}<0.05)$ in $\mathrm{PGF}_{2 \alpha}$ treated rats compared to PBS treated rats. On the other hand, the AUP for $\mathrm{P}_{4}$ peak was significantly decreased $(p<0.01)$ in serum from $\mathrm{PGF}_{2 \alpha}$ treated rats compared to serum from PBS treated rats.

Similar to HPLC analysis of samples from rats, serum samples from buffalo cows receiving no treatment $(0 \mathrm{~h})$ and from animals receiving $\mathrm{PGF}_{2 \alpha}$ injection at $18 \mathrm{~h}$ time point were subjected to chromatographic analysis and a representative chromatogram pattern is presented in Figure 5. The sum total result of AUP values is represented in Table 2. The mixture of steroids at a concentration of $5 \mathrm{ng} / 10 \mu \mathrm{l}$ for each HPLC run was analysed under identical HPLC conditions as shown in Figures $4 \mathrm{~A}$ and $5 \mathrm{~A}$. The

Table 1 HPLC analysis for different concentrations of 20a-OHP and $\mathbf{P}_{4}$ expressed as area under peak

\begin{tabular}{ccccc}
\hline $\begin{array}{l}\text { Standards } \\
\text { (ng/10 } \boldsymbol{\mu l})\end{array}$ & $\mathbf{3 3}$ & $\mathbf{1 0}$ & $\mathbf{3 . 3}$ & $\mathbf{1}$ \\
\hline $20 \mathrm{a}-\mathrm{OHP}$ & $119.15 \pm 5.22$ & $35.71 \pm 4.68$ & $15.64 \pm 6.99$ & $4.45 \pm 1.99$ \\
$P_{4}$ & $102.48 \pm 4.72$ & $33.69 \pm 4.49$ & $14.51 \pm 6.49$ & $5.03 \pm 2.25$ \\
\hline
\end{tabular}

Value represents mean \pm SEM, in units.
AUP for $\mathrm{P}_{4}$ peak significantly decreased $(\mathrm{p}<0.05)$ in serum from $18 \mathrm{~h}$ post $\mathrm{PGF}_{2 \alpha}$ injected buffalo cows compared to serum of untreated buffalo cows (time $0 \mathrm{~h}$ ) on day 11 of the estrous cycle (Figure 5B and C).

Determination of luteal $20 a-H S D$ activity in $\mathrm{CL}$ of pseudo pregnant rats and buffalo cows after $\mathrm{PGF}_{2 a}$ treatment

Figure 6 shows the 20 -HSD activity both in rat and buffalo cow CL cytosolic fractions. The $20 \alpha-\mathrm{HSD}$ specific activity (Figure 6A) was significantly higher $(\mathrm{p}<0.01)$ in luteal tissue from $\mathrm{PGF}_{2 \alpha}$ treated rats compared to PBS treated rats $\left(0.412 \pm 0.02\right.$ vs $0.171 \pm 0.03$ nmoles $\mathrm{min}^{-1} \mathrm{mg}^{-1}$ for $\mathrm{CL}$ from animals receiving $\mathrm{PGF}_{2 \alpha}$ and $\mathrm{PBS}$ treatment, respectively). On the other hand, examination of specific activity of $20 \alpha-H S D$ in cytosolic fractions of CL from $\mathrm{PGF}_{2 \alpha}$-treated buffalo cows at various time points did not change and tended to be lower from $0 \mathrm{~h}$ time point (Figure 6B).

\section{Discussion}

Corpus luteum is a transient endocrine structure formed from the ovarian follicle after ovulation. Through biosynthesis and secretion of $\mathrm{P}_{4}$, it plays a pivotal role in the control of reproduction in mammals. The precise timing of expression of various enzymes/proteins required for synthesis and metabolism of $\mathrm{P}_{4}$ constitutes an important process in the regulation of CL function. In several species including the buffalo cow, $\mathrm{PGF}_{2 \alpha}$ functions as a physiological luteolysin that curtails CL function at the end of 


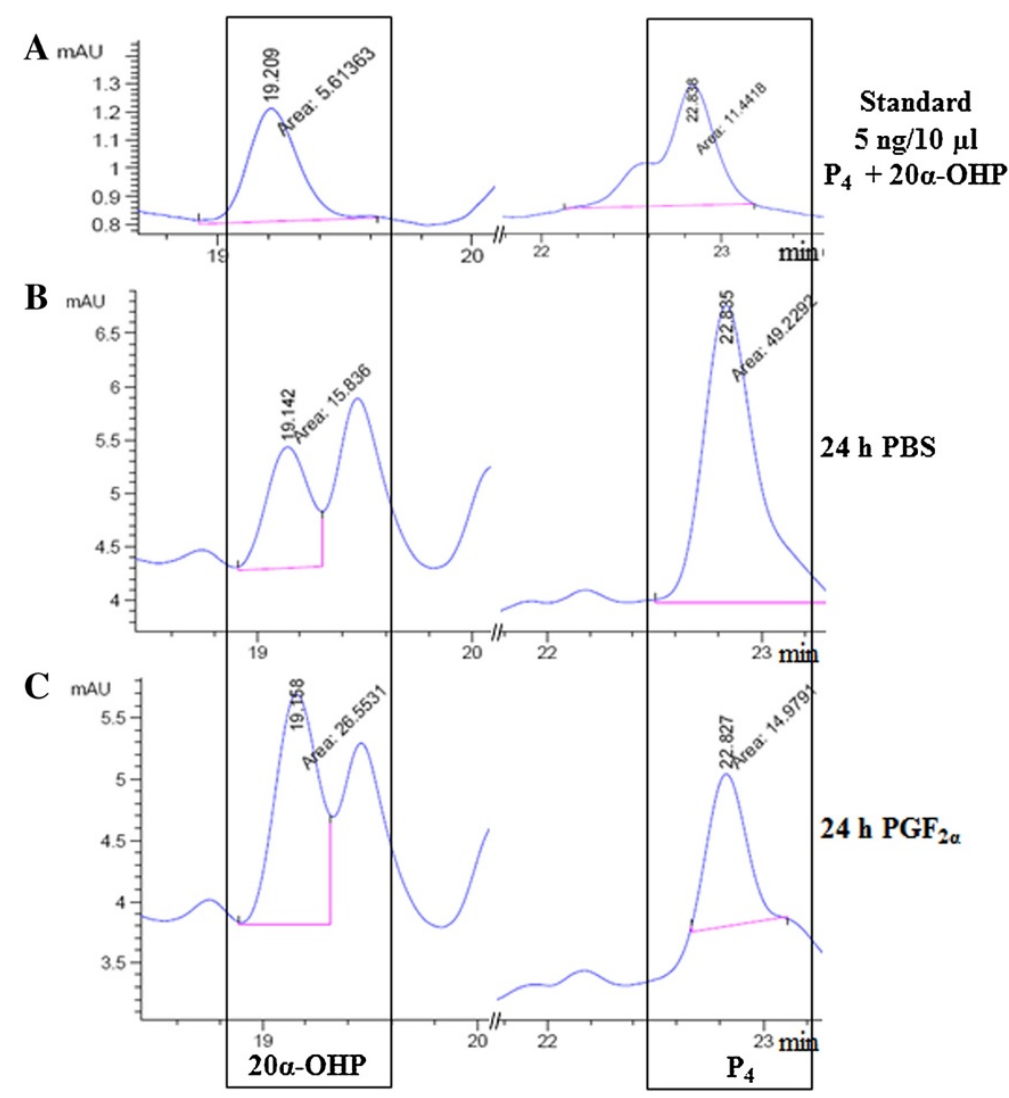

Figure 4 Chromatograms of $20 a-O H P$ and $\mathrm{P}_{4}$ in serum samples from pseudo pregnant rats. (A) A concentration of 5 ng each of $20 a-O H P$ and $\mathrm{P}_{4}$ was used during HPLC run. The peak for 20a-OHP and $\mathrm{P}_{4}$ were noted down at 19.1 and 22.8 min, respectively. (B) and (C) Chromatogram profiles of extracted serum samples collected from pseudo pregnant rats, $24 \mathrm{~h}$ treatment with PBS (control) or PGF $2 a$ (treatment) are shown. The peaks of $20 \mathrm{a}-\mathrm{OHP}$ and $\mathrm{P}_{4}$ were indicated at the respective run times for each steroid.

non-pregnant cycle and prior to parturition [23-26]. Despite its central role in luteolysis, $\mathrm{PGF}_{2 \alpha}$ actions on CL leading to decrease in $\mathrm{P}_{4}$ secretion and subsequent apoptotic changes have not been clearly elucidated. In rats, it is well documented that the initial decrease in luteal function that occurs post $\mathrm{PGF}_{2 \alpha}$ treatment is precipitated by an increase in $\mathrm{P}_{4}$ metabolism i.e. $\mathrm{P}_{4}$ gets converted to its inactive metabolite $20 \alpha-\mathrm{OHP}$ rather than a decrease in its synthesis [9]. The stimulatory effect of $\mathrm{PGF}_{2 \alpha}$ on $20 \alpha-$ HSD expression in the CL tissue is well recognised in rodents [27-30]. In ruminants including the buffalo cow, $\mathrm{PGF}_{2 \alpha}$ causes marked rapid decline in circulating concentration of $\mathrm{P}_{4}$ (unpublished data from the laboratory, Davis

Table 2 HPLC analysis of $20 a-O H P$ and $P_{4}$ expressed as area under peak in rats and buffalo cows

\begin{tabular}{|c|c|c|c|c|}
\hline \multirow[t]{2}{*}{ Treatments } & \multicolumn{2}{|c|}{ Rat } & \multicolumn{2}{|c|}{ Buffalo cow } \\
\hline & 24 h PBS & 24 h $\mathrm{PGF}_{2 a}$ & $0 \mathrm{~h} \mathrm{PGF}_{2 \mathrm{a}}$ & $18 \mathrm{~h} \mathrm{PGF}_{2 \mathrm{a}}$ \\
\hline $20 a-O H P$ & $22.79 \pm 3.58^{\mathrm{a}}$ & $33.59 \pm 2.99^{b}$ & ND & ND \\
\hline$P_{4}$ & $55.89 \pm 3.58^{c}$ & $23.09 \pm 3.37^{d}$ & $22.02 \pm 3.14^{x}$ & $13.18 \pm 1.25^{y}$ \\
\hline
\end{tabular}

Value represents mean $\pm S E M ; N D=$ Non-detectable; $p<0.05$ (a vs $b, x$ vs $y$ ) and $p<0.01$ ( $c$ vs d). et al., 2010). As the initial actions of $\mathrm{PGF}_{2 \alpha}$ on the CL are not well defined, it became of interest to examine whether $\mathrm{PGF}_{2 \alpha}$ treatment in buffalo cows during luteal phase leads to formation of inactive metabolite such as $20 \alpha-\mathrm{OHP}$. Since the CL of ruminants unlike rodents express $\mathrm{P}_{4}$ receptors, it can be argued that perhaps initial decline in $\mathrm{P}_{4}$ that occurs in response to $\mathrm{PGF}_{2 \alpha}$ treatment leads to changes in expression of genes associated with control of luteal function [23,31-33].

In order to determine whether rapid decline in circulating $\mathrm{P}_{4}$ was due to its conversion to inactive metabolites, present studies were carried out to examine the activity of $20 \alpha-H S D$ during induced luteolysis in buffalo cows. The results of the present studies demonstrate expression of $20 \alpha-H S D$ in CL and other tissues of the buffalo cow. The importance of $20 \alpha-\mathrm{HSD}$ expression in tissues such as spleen, brain and liver is unclear but may be associated with steroid metabolism [18]. Furthermore, despite the increased expression of $20 \alpha-\mathrm{HSD}$ post $\mathrm{PGF}_{2 \alpha}$ treatment, its enzyme activity remained low in the $\mathrm{CL}$ during $\mathrm{PGF}_{2 \alpha}$ treatment. Also, circulating concentration of $20 \alpha-\mathrm{OHP}$ did not increase post $\mathrm{PGF}_{2 \alpha}$ treatment. It is not clear why 


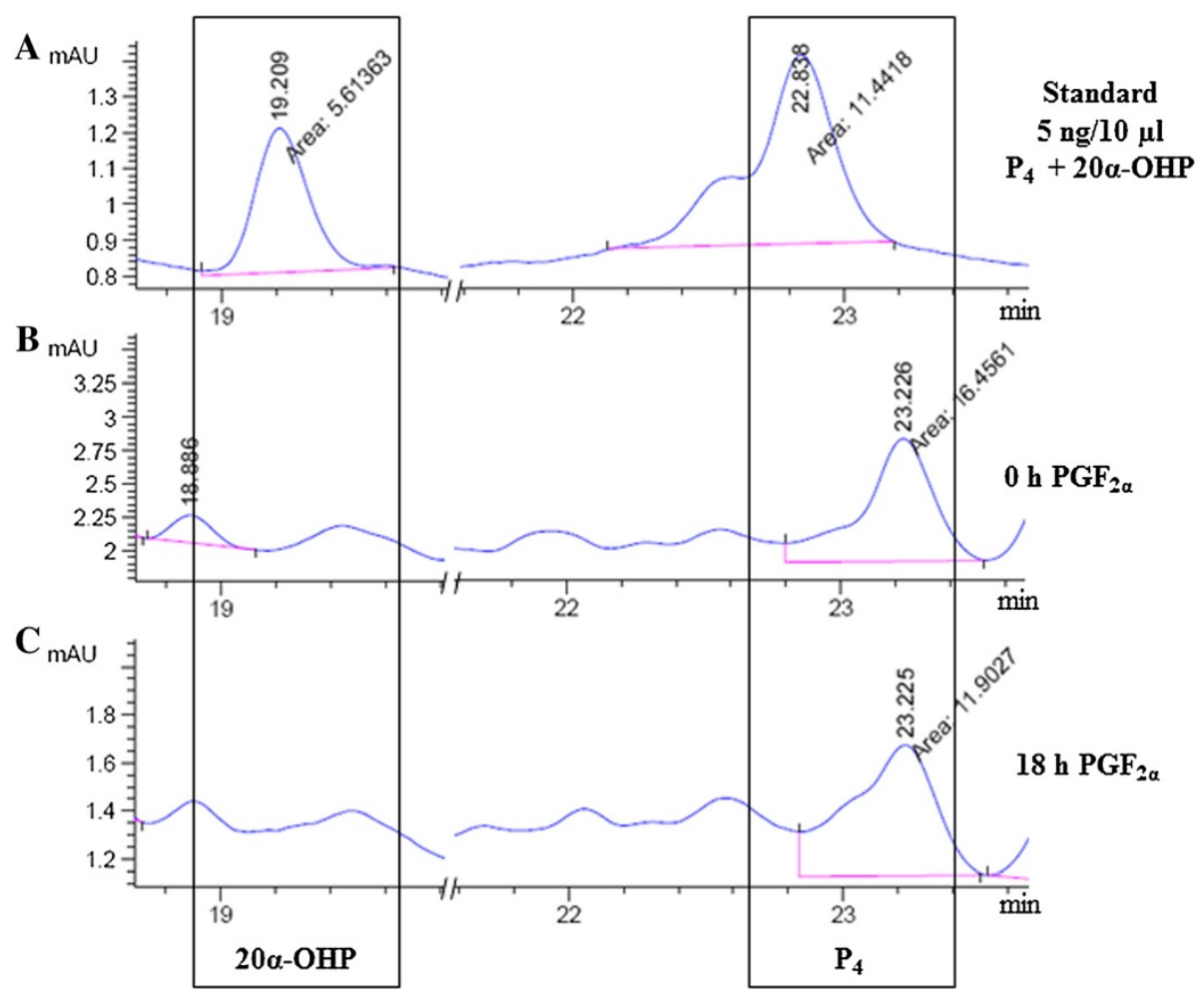

Figure 5 Chromatograms of $20 a-O H P$ and $\mathrm{P}_{4}$ in buffalo cow serum samples before and after $\mathrm{PGF}_{2 a}$ treatment. (A) The standard mixture of steroids comprising of $5 \mathrm{ng}$ each of 20a-OHP and $\mathrm{P}_{4}$ was used during HPLC run. The peak for 20a-OHP and $\mathrm{P}_{4}$ were noted down at 19.1 and $22.8 \mathrm{~min}$, respectively. Chromatogram showing steroids extracted from serum collected at $0 \mathrm{~h}$ (B) and $18 \mathrm{~h}$ (C) post PGF ${ }_{2 a}$ treatment in the buffalo cow are shown.

an increased expression of $20 \alpha-$ HSD was not associated with its increased translation and activity post PGF $_{2 \alpha}$ treatment. One explanation could be that $\mathrm{PGF}_{2 \alpha}$ treatment was detrimental to translational machinery. None the less, the results taken together indicate that decreased circulating $\mathrm{P}_{4}$ concentration seen in response to the luteolytic dose of $\mathrm{PGF}_{2 \alpha}$ treatment does not appear to be the result of metabolism of $\mathrm{P}_{4}$ in buffalo cows. The present observation of lack of change in $20 \alpha-\mathrm{OHP}$ concentration in response to $\mathrm{PGF}_{2 \alpha}$ treatment in buffalo cows is in contrast to results reported in rodents by others $[3,7,8]$ and as observed in the present rat studies.

In species such as rodents that do not express classical $\mathrm{P}_{4}$ receptors in $\mathrm{CL}$, it becomes of interest to examine
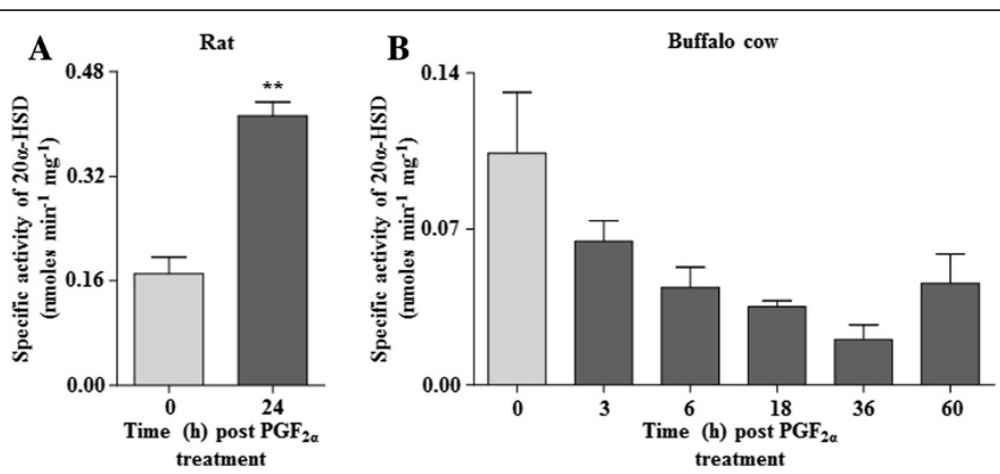

Figure 6 Activity of cytosolic 20a-HSD in luteal tissue of pseudo pregnant rats and buffalo cows. The enzyme activity is expressed as nmoles NADPH min-1 $\mathrm{mg}^{-1}$ with 1 unit of activity defined as the amount of enzyme that can induce formation of $1 \mathrm{nmole} \mathrm{NADP} \mathrm{min}^{-1} \mathrm{mg}^{-1}$ extract used at $37^{\circ} \mathrm{C}$. (A) Specific activity of $20 \mathrm{a}-\mathrm{HSD}$ at 0 and $24 \mathrm{~h}$ post $\mathrm{PGF}_{2 \mathrm{a}}$ treated pseudo pregnant rat $\mathrm{CL}$ cytosolic extract. (B) Specific activity of $20 \mathrm{a}-\mathrm{HSD}$ at $\mathrm{0}, 3,6,18,36$ and $60 \mathrm{~h}$ post PGF $2 a$ treated buffalo $\mathrm{CL}$ cytosolic extract. The cytosolic extract from the luteal tissue collected without PGF $2 a$ treatment $(0 \mathrm{~h})$ was designated as control. Each bar represents mean $\pm \mathrm{SEM}, \mathrm{n}=5$ /time point for pseudo pregnant rats and $\mathrm{n}=3 /$ time point for buffalo cows, ${ }^{* *} \mathrm{p}<0.01,0 \mathrm{~h}$ versus different time points. 
whether fall in $\mathrm{P}_{4}$ concentration that occurs due to catabolism is sufficient and necessary for initiation of process of luteolysis. Also, the regulation of $20 \alpha-\mathrm{HSD}$ expression has to be taken into consideration during $\mathrm{PGF}_{2 \alpha}$-mediated actions on the luteal tissue. It has been shown that prolactin regulates $20 \alpha-H S D$ expression and inhibition of prolactin secretion results in rapid rise in 20 $\alpha$-HSD expression [34-37]. Whether prolactin has a role in the regulation of $20 \alpha-H S D$ expression and whether $\mathrm{PGF}_{2 \alpha}$ influences prolactin signaling or other factors in the regulation of $20 \alpha-H S D$ need to be investigated. However, it should be pointed out that few studies carried out employing targeted deletion of $20 \alpha-H S D$ in mice model seems to suggest a minor role for catabolism of $\mathrm{P}_{4}$ in the

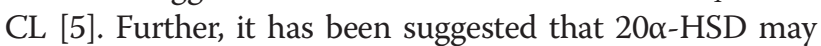
have an important role in the regulation of $\mathrm{P}_{4}$ levels in the placenta for growth and development of foetus rather than regulating $\mathrm{P}_{4}$ levels systemically $[1,2,5]$.

Several studies have suggested participation of Nur77 during parturition process as well as after exogenous $\mathrm{PGF}_{2 \alpha}$ treatment $[3,7,8]$. In the present study, a rapid induction of Nur77 expression in CL in response to $\mathrm{PGF}_{2 \alpha}$ treatment in buffalo cows was also observed. In mice, studies have been carried out extensively to demonstrate that Nur77 binds to the promoter region of $20 \alpha-H S D$ leading to increased transcription [8]. The participation of Nur77 in the regulation of expression of other steroidogenic genes such as adrenal 21-hydroxylase [38], ovarian 3 $\beta$-HSD [39], 20 $\alpha-$ HSD and aromatase as well as StAR, CYP11A1 and CYP17 genes have been reported $[11,12]$. In addition to transcriptional activation of $20 \alpha-$ HSD expression, Nur77 has been implicated in thymocytic apoptosis following activation of MAP kinases particularly JNK, p38, and possibly ERK5 [40]. The PGF $2 \alpha$-induced luteolysis appears to be initiated through activation of phospholipase C. Earlier reports have suggested a lack of direct participation of PKC during the luteolytic process, but increased intracellular $\mathrm{Ca}^{+2}$ and activation of ERK pathway by Nur77 have been suggested to be involved in the $\mathrm{PGF}_{2 \alpha}$-mediated actions in the rat $\mathrm{CL}[41,42]$. Incidentally, it should be pointed out that several MAP kinases are activated during $\mathrm{PGF}_{2 \alpha}$-induced luteolysis in the CL of buffalo cows [23] and involvement of MAP kinase pathways have been implicated in the induction of Nur77 expression [40,43]. The above observations point to a critical role of Nur77 in the activation of apoptotic pathway. In the present study, the observation of increased expression of Nur77 suggests that it may be associated with activation of apoptotic pathway, and this is further supported by the observation of increased JAK and p38 activity in CL from buffalo cows treated with $\mathrm{PGF}_{2 \alpha}$ [23]. However, it remains to be determined what role, if any, Nur77 has in pathways/molecules associated with rapid fall in $\mathrm{P}_{4}$. Also, whether Nur77 is responsible for increased expression of $20 \alpha-$ HSD remains to be determined.

\section{Conclusions}

In conclusion, studies carried out to examine 20 $\alpha-\mathrm{HSD}$ expression and circulating $20 \alpha-\mathrm{OHP}$ levels in the buffalo cow indicated expression of $20 \alpha-\mathrm{HSD}$ in the CL and it transiently increased at 3 and $18 \mathrm{~h}$ post $\mathrm{PGF}_{2 \alpha}$ treatment, but this was not accompanied by increased activity of $20 \alpha-H S D$. The results also indicated that Nur77, the transcription factor that has been implicated in transcriptional increase of $20 \alpha-\mathrm{HSD}$ expression in rodents was also transiently increased in the buffalo cow $\mathrm{CL}$ post $\mathrm{PGF}_{2 \alpha}$ treatment. The results taken together suggest that catabolism of $\mathrm{P}_{4}$ does not occur in cattle post $\mathrm{PGF}_{2 \alpha}$ treatment.

\section{Competing interests}

The authors declare that they have no competing interests.

\section{Authors' contributions}

TS and RM participated in designing, conducting experiments, analysis of results and preparation of manuscript. KA participated in the preparation of manuscript. All authors have read and approved the final manuscript.

\section{Acknowledgements}

Financial support by ICAR (NFBSRA \& NAIP) and DBT, India, to conduct these studies is gratefully acknowledged.

Received: 15 August 2013 Accepted: 9 December 2013

Published: 11 December 2013

\section{References}

1. Jayasekara WS, Yonezawa T, Ishida M, Yamanouchi K, Nishihara M: Molecular cloning of goat 20alpha-hydroxysteroid dehydrogenase cDNA. J Reprod Dev 2004, 50:323-331.

2. Jayasekara WS, Yonezawa T, Ishida M, Yamanouchi K, Nishihara M: Expression and possible role of 20alpha-hydroxysteroid dehydrogenase in the placenta of the goat. J Reprod Dev 2005, 51:265-272.

3. Waddell BJ, Benediktsson R, Seckl JR: 11 beta-Hydroxysteroid dehydrogenase type 2 in the rat corpus luteum: induction of messenger ribonucleic acid expression and bioactivity coincident with luteal regression. Endocrinology 1996, 137:5386-5391.

4. Ishida M, Choi JH, Hirabayashi K, Matsuwaki T, Suzuki M, Yamanouchi K, Horai R, Sudo K, Iwakura Y, Nishihara M: Reproductive phenotypes in mice with targeted disruption of the 20alpha-hydroxysteroid dehydrogenase gene. J Reprod Dev 2007, 53:499-508.

5. Choi JH, Ishida M, Matsuwaki T, Yamanouchi K, Nishihara M: Involvement of 20alpha-hydroxysteroid dehydrogenase in the maintenance of pregnancy in mice. J Reprod Dev 2008, 54:408-412.

6. Wiest WG, Kidwell WR, Balogh K Jr: Progesterone catabolism in the rat ovary: a regulatory mechanism for progestational potency during pregnancy. Endocrinology 1968, 82:844-859.

7. Kuhn NJ, Briley MS: The roles of pregn-5-ene-3 beta, 20 alpha-diol and 20 alpha-hydroxy steroid dehydrogenase in the control of progesterone synthesis preceding parturition and lactogenesis in the rat. Biochem J 1970, 117:193-201.

8. Stocco CO, Zhong L, Sugimoto Y, Ichikawa A, Lau LF, Gibori G: Prostaglandin F2alpha-induced expression of 20alpha-hydroxysteroid dehydrogenase involves the transcription factor NUR77. J Biol Chem 2000, 275:37202-37211.

9. Stocco C, Callegari E, Gibori G: Opposite effect of prolactin and prostaglandin $\mathrm{F}$ (2 alpha) on the expression of luteal genes as revealed by rat CDNA expression array. Endocrinology 2001, 142:4158-4161.

10. Wingate $A D$, Arthur JS: Post-translational control of Nur77. Biochem SoC Trans 2006, 34:1107-1109. 
11. Li M, Xue K, Ling J, Diao FY, Cui YG, Liu JY: The orphan nuclear receptor NR4A1 regulates transcription of key steroidogenic enzymes in ovarian theca cells. Mol Cell Endocrinol 2010, 319:39-46.

12. Wu Y, Ghosh S, Nishi Y, Yanase T, Nawata H, Hu Y: The orphan nuclear receptors NURR1 and NGFI-B modulate aromatase gene expression in ovarian granulosa cells: a possible mechanism for repression of aromatase expression upon luteinizing hormone surge. Endocrinology 2005, $146: 237-246$.

13. Liu ZG, Smith SW, McLaughlin KA, Schwartz LM, Osborne BA: Apoptotic signals delivered through the T-cell receptor of a T-cell hybrid require the immediate-early gene nur77. Nature 1994, 367:281-284.

14. Woronicz JD, Calnan B, Ngo V, Winoto A: Requirement for the orphan steroid receptor Nur77 in apoptosis of T-cell hybridomas. Nature 1994, 367:277-281.

15. Lin B, Kolluri SK, Lin F, Liu W, Han YH, Cao X, Dawson MI, Reed JC, Zhang XK: Conversion of $\mathrm{Bcl}-2$ from protector to killer by interaction with nuclear orphan receptor Nur77/TR3. Cell 2004, 116:527-540.

16. Weih F, Ryseck RP, Chen L, Bravo R: Apoptosis of nur77/N10-transgenic thymocytes involves the Fas/Fas ligand pathway. Proc Natl Acad Sci 1996, 93:5533-5538

17. Naidansuren P, Park CW, Kim SH, Nanjidsuren T, Park JJ, Yun SJ, Sim BW, Hwang S, Kang MH, Ryu BY, Hwang SY, Yoon JT, Yamanouchi K, Min KS: Molecular characterization of bovine placental and ovarian 20a-hydroxysteroid dehydrogenase. Reproduction 2011, 142:723-731.

18. Asselin E, Fortier MA: Detection and regulation of the messenger for a putative bovine endometrial 9-keto-prostaglandin $\mathrm{E}(2)$ reductase: effect of oxytocin and interferon-tau. Biol Reprod 2000, 62:125-131.

19. Pharriss BB, Wyngarden $L$ : The effect of prostaglandin $F$ 2alpha on the progestogen content of ovaries from pseudopregnant rats. Proc Soc Exp Biol Med 1969, 130:92-94.

20. Jyotsna UR, Medhamurthy R: Standardization and validation of an induced ovulation model system in buffalo cows: characterization of gene expression changes in the periovulatory follicle. Anim Reprod Sci 2009, 113:71-81

21. Priyanka S, Jayaram P, Sridaran R, Medhamurthy R: Genome-wide gene expression analysis reveals a dynamic interplay between luteotropic and luteolytic factors in the regulation of corpus luteum function in the bonnet monkey (Macaca radiata). Endocrinology 2009, 150:1473-1484.

22. Liu ZL, Palmquist DE, Ma M, Liu J, Alexander NJ: Application of a master equation for quantitative mRNA analysis using qRT-PCR. J Biotechnol 2009, 143:10-16.

23. Yadav VK, Sudhagar RR, Medhamurthy R: Apoptosis during spontaneous

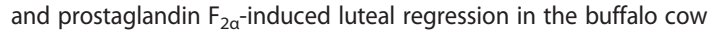
(Bubalus bubalis): involvement of mitogen-activated protein kinases. Biol Reprod 2002, 67:752-759

24. Yadav VK, Lakshmi G, Medhamurthy R: Prostaglandin F2alpha-mediated activation of apoptotic signaling cascades in the corpus luteum during apoptosis: involvement of caspase-activated DNase. J Biol Chem 2005, 280:10357-10367.

25. Niswender GD, Juengel JL, Silva PJ, Rollyson MK, Mclntush EW: Mechanisms controlling the function and life span of the corpus luteum. Physiol Rev 2000, 80:1-29.

26. Stocco C, Telleria C, Gibori G: The molecular control of corpus luteum formation, function, and regression. Endocr Rev 2007, 28:117-149.

27. Strauss JF, Stambaugh RL: Induction of 20 alpha-hydroxysteroid dehydrogenase in rat corpora lutea of pregnancy by prostaglandin F-2 alpha. Prostaglandins 1974, 5:73-85.

28. Bussmann LE, Deis RP: Studies concerning the hormonal induction of lactogenesis by prostaglandin F2 alpha in pregnant rats. J Steroid Biochem 1979, 11:1485-1489.

29. Kawano T, Okamura H, Tajima C, Fukuma K, Katabuchi H: Effect of RU 486 on lutealfunction in the early pregnant rat. J Reprod Fertil 1988, 83:279-285.

30. Telleria CM, Stocco CO, Deis RP: Luteolytic action of RU486: modulation of luteal 3 beta-hydroxysteroid dehydrogenase and 20 alphahydroxysteroid dehydrogenase activities in late pregnant rats. J Steroid Biochem Mol Biol 1995, 52:567-573.

31. Shaw DW, Britt JH: Concentrations of tumor necrosis factor alpha and progesterone within the bovine corpus luteum sampled by continuous-flow microdialysis during luteolysis in vivo. Biol Reprod 1995, 53:847-854.

32. Ginther OJ, Araujo RR, Palhão MP, Rodrigues BL, Beg MA: Necessity of sequential pulses of prostaglandin F2alpha for complete physiologic luteolysis in cattle. Biol Reprod 2009, 80:641-648.
33. Arvisais E, Hou X, Wyatt TA, Shirasuna K, Bollwein H, Miyamoto A, Hansen TR, Rueda BR, Davis JS: Prostaglandin F2alpha represses IGF-I stimulated IRS1/ phosphatidylinositol-3-kinase/AKT signaling in the corpus luteum: role of ERK and P70 ribosomal S6 kinase. Mol Endocrinol 2010, 3:632-643.

34. Albarracin CT, Parmer TG, Duan WR, Nelson SE, Gibori G: Identification of a major prolactin-regulated protein as 20 alpha-hydroxysteroid dehydrogenase: coordinate regulation of its activity, protein content, and messenger ribonucleic acid expression. Endocrinology 1994, 134:2453-2460.

35. Piekorz RP, Gingras S, Hoffmeyer A, Ihle JN, Weinstein Y, Weinstein Y: Regulation of progesterone levels during pregnancy and parturition by signal transducer and activator of transcription 5 and 20alphahydroxysteroid dehydrogenase. Mol Endocrinol 2005, 19:431-440.

36. Bao L, Tessier C, Prigent-Tessier A, Li F, Buzzio OL, Callegari EA, Horseman ND, Gibori G: Decidual prolactin silences the expression of genes detrimental to pregnancy. Endocrinology 2007, 148:2326-2334.

37. Clementi MA, Deis RP, Telleria CM: Luteal 3beta-hydroxysteroid dehydrogenase and 20alpha-hydroxysteroid dehydrogenase activities in the rat corpus luteum of pseudopregnancy: effect of the deciduoma reaction. Reprod Biol Endocrinol 2004, 2:22.

38. Wilson TE, Mouw AR, Weaver CA, Milbrandt J, Parker KL: The orphan Nuclear receptor NGFI-B regulates expression of the gene encoding steroid 21- hydroxylase. Mol Cell Biol 1993, 13:861-868.

39. Havelock JC, Smith AL, Seely JB, Dooley CA, Rodgers RJ, Rainey WE, Carr BR: The NGFI-B family of transcription factors regulates expression of 3beta- hydroxysteroid dehydrogenase type 2 in the human ovary. Mol Hum Reprod 2005, 11:79-85.

40. Sohn SJ, Thompson J, Winoto A: Apoptosis during negative selection of autoreactivethymocytes. Curr Opin Immunol 2007, 19:510-515.

41. Mizukami Y, Kobayashi S, Uberall F, Hellbert K, Kobayashi N, Yoshida K: Nuclear mitogen-activated protein kinase activation $C \zeta$ during reoxygenation after ischemic hypoxia. J Biol Chem 2000, 275:19921-19927.

42. Rojnukarin P, Miyakawa Y, Fox NE, Deou J, Daum G, Kaushansky K: The roles of phosphatidylinositol 3-kinase and protein kinase $C \zeta$ for thrombopoietin-induced mitogen-activated protein kinase activation in primary murine megakaryocytes. J Biol Chem 2001, 276:41014-41022.

43. Kovalovsky D, Refojo D, Liberman AC, Hochbaum D, Pereda MP, Coso OA, Stalla GK, Holsboer F, Arzt E: Activation and induction of Nur77/ Nurr1 in corticotrophs by $\mathrm{CRH} / \mathrm{CAMP}$ : involvement of calcium, protein kinase $\mathrm{A}$, and MAPK pathways. Mol Endocrinol 2002, 16:1638-1651.

doi:10.1186/1477-7827-11-111

Cite this article as: Sudeshna et al:: Analysis of 20alpha-hydroxysteroid dehydrogenase expression in the corpus luteum of the buffalo cow: effect of prostaglandin F2-alpha treatment on circulating 20alpha-

hydroxyprogesterone levels. Reproductive Biology and Endocrinology 2013 11:111.

\section{Submit your next manuscript to BioMed Central and take full advantage of:}

- Convenient online submission

- Thorough peer review

- No space constraints or color figure charges

- Immediate publication on acceptance

- Inclusion in PubMed, CAS, Scopus and Google Scholar

- Research which is freely available for redistribution 